\title{
PRIORITY RATING OF COUNTRIES OF THE WORLD FOR UKRAINE'S NATIONAL INTERESTS
}

\author{
Valentyn STAFIICHUK \\ Taras Shevchenko National University of Kyiv, Ukraine \\ valikosta@ukr.net
}

\begin{abstract}
After the Russian occupation of Crimea and a part of Donbas the political and geographical position of Ukraine as well as its positioning in the modern world significantly changed. Previously, Ukraine had placed greater focus on non-bloc status in the multipolar world and on development of mutually beneficial bilateral relations with all its partners.

For this reason, it is very important to calculate the country priority rating for Ukraine. This rating contains two groups of indicators from all spheres of interstate relations. The first group shows the current level of interaction and the second group shows the importance of states in the modern world.

From six priority groups of countries the top-priority for Ukraine is cooperation with Germany, the USA, the United Kingdom, the Netherlands, Italy, France, Canada, Spain and Switzerland. The second priority group includes most of European countries (such as the Czech Republic, Poland, Austria, Belgium, Sweden, Denmark, Portugal, Hungary, Romania, Norway, Iceland, Finland, Slovakia), Japan, Israel, Australia, South Korea, Turkey and Singapore. Contrary to popular belief of supporters of indispensable friendship with Russia this country is not so important for cooperation nowadays and, moreover, it is not a landmark for the future as it is only in the third priority group. This group also includes Bulgaria, Malaysia, China, New Zealand, Estonia, Greece, Latvia, Thailand, Brazil, etc.

Cooperation with more prosperous countries will help to get rid of the negative moments of Russian colonization, to reach higher economic and socio-political standards.

With certain modifications this rating can be used for calculation of cooperation priority ratings for any country in the world.
\end{abstract}

Key words: priority rating, geostrategy, national interests, Ukraine, EU, NATO, USA, Russia.

DOI: https://doi.org/10.17721/2413-7154/2020.84.13-22

UDC: $911.3: 32(477+100)$

Received: July 16, 2020.

Revised: October 28, 2020.

Accepted: December 23, 2020.

\section{РЕЙТИНГ ПРІОРИТЕТНОСТІ ДЕРЖАВ СВІТУ ВІДПОВІДНО ДО НАЦІОНАЛЬНИХ ІНТЕРЕСІВ УКРАЇНИ}

\author{
Валентин СТАФІЙчУК \\ Київський начіональний університет імені Тараса Шевченка, Україна \\ valikosta@ukr.net
}

Анотація: В умовах російської окупації Криму та частини Донбасу суттєво змінилося політико-географічне положення та позиціонування України в сучасному світі. Якщо раніше країна, базуючись на своєму без'ядерному статусі, більше акцентувала увагу на позаблоковості у багатополюсному світі та розвитку взаємовигідних стосунків з усіма партнерами, то нині вона поставлена в умови виживання.

Нами запропоновано рейтинг пріоритетності країн для України відповідно до її сучасних національних інтересів і стратегічних цілей. При формуванні рейтингу були використали дві групи показників, які характеризують усі сфери міждержавних відносин: перша показує нинішній рівень взаємодії, а друга - вагу держав у сучасному світі.

Всі країни були поділені на шість груп пріоритетності. Найбільш пріоритетною для України $\epsilon$ співпраця у всіх сферах з Німеччиною, США, Великою Британією, Нідерландами, Італією, Францією, Канадою, Іспанією, Швейцарією. Більшість європейських держав входять до другої групи пріоритетності. Співпраця з більш успішними в економічному і політичному планах країнами допоможе швидше позбутися негативних моментів російської колонізації, розвіяти російські міти, досягти вищих економічних та суспільно-політичних стандартів. Попри поширену думку, Росія не $\epsilon$ важливою для співпраці нині і, тим паче, орієнтиром у майбутньому та входить лише у третю групу пріоритетності.

Ключові слова: рейтинг пріоритетності, геостратегія, національні інтереси, Україна, ЄС, НАТО, США, Росія. 
Вступ. Актуальність дослідження. 3 часів Київської Русі стояла проблема вибору адекватних партнерів на міжнародній арені. Інколи цей вибір був продиктований особистими вподобаннями окремих правителів, інколи - необхідністю виживання існуючих державних утворень, а ще частіше інтересами тих, хто колонізував і ділив українські землі. Інтереси колонізаторів, як правило, йшли в розріз із прагненнями самих українців. Як от за часів національно-визвольних змагань середини XVII i на початку та всередині XX століть. Дуже часто українці були поставлені у вузькі рамки вибору між поганим варіантом і ще гіршим. Як правило, вибір найчастіше обмежувався сусідами: Візантією, Польщею, Великим князівством Литовським, Московією (Російською імперією, СРСР), Османською імперією (Туреччиною), Австро-Угорщиною; інколи надії покладалися на дружбу і заступництво більш віддалених держав - Німеччини, США, Великої Британії.

Зі здобуттям незалежності у 1991 р Україна, здавалось би, отримала шанс самостійно обирати курс свого розвитку і партнерів, які б відповідали iii національним інтересам. Першопочатково було задекларовано позаблоковий статус i прагнення розвивати взаємовигідне співробітництво 3 усіма державами світу, особливо сусідами, членами Європейського Союзу (СС), США і навіть авторитарно-комуністичним Китаєм. Проте Росія не мала жодного наміру «випускати» Україну зі сфери свого впливу. Для цього вона задіяла весь арсенал політичних, економічних та культурноінформаційних методів впливу і маніпуляцій.

Після Революції Гідності та окупації Росією, всупереч усім міжнародним та двостороннім договорам, Криму i частини українського Донбасу здавалося, що 3 домінуванням Росії в Україні покінчено назавжди. Україна підписала відповідну Угоду з СС та відмовилася від курсу на позаблоковість. Стратегічний курс на членство в СС і НАТО було прописано в Конституції та низці інших документів. Проте агресивна гібридна війна Росії проти України, певні внутрішні проблеми зумовили не лише повернення проросійської риторики в українську політику, а й створили реальну загрозу реваншу проросійських сил. Окремі проросійські політики, на підконтрольних їм каналах і в засобах масової інформації (3МI), переконують українців у необхідності інтеграції 3 агресором, маніпулюючи історичними фактами, реальними даними про стан взаємодії, тезами про «братерство», «спільну колиску» та іншими міфами «русского мира», який поєднав найодіозніші ідеї панславізму, православ'я, інтернаціоналізму, комунізму та сучасного російського націонал-фашизму. Український політикум майже на 30-му році незалежності так остаточно i не забезпечив непохитність задекларованого вектору геостратегії держави.

Таким чином, бачимо, що проблема вибору партнерів відповідно до стратегічних інтересів держави, залишається відкритою. Більше того, часта зміна Україною векторів зовнішньої політики негативно впливає на такий вибір, створюючи образ непередбачуваного партнера, що, до речі, також $є$ частиною російської стратегії та інформаційної війни проти нашої держави і намаганні виставити Україну «failed state».

Отже, актуальність даного дослідження зумовлена низкою запитань, які все ще залишаються без відповіді. Перш за все: «Стосунки 3 якими державами світу найбільшою мірою відповідають стратегічним національним інтересам України?»

Аналіз останніх досліджень. Попри злободенність вище поставленого запитання, у науковому середовищі, як i в політикумі, досі відсутній єдиний погляд на стратегію української держави. Звісно, що після 2014 р переважає розгляд СC і НАТО як найбільш пріоритетного вектору, проте окремі дослідники обгрунтовують й інші, на їхню думку, найдоцільніші напрямки української геостратегії.

При цьому українські географи найчастіше звертають увагу на дво- та багатосторонню економічну і політичну співпрацю України з СС, НАТО, США, Росією, пострадянським простором, балто-чорноморськими чи близькосхідними державами, Китаєм (наприклад, Н. Корома (2007), М. Мальський та О. Кучик (2013), А. Мельничук (2011), В. Моргацький (2019), С. Хорошенюк (2017)). Цілком традиційними є дослідження політико-географічного (М. Дністрянський (2010), О. Малиновська та В. Стафійчук (2017), Р. Сливка (2011), О. Шаблій (2004)) та геополітичного (Р. Клочко (2007), С. Лавриненко (2014), С. Лотоцький та С. Трохимчук (2002), M. Паламарчук та О. Паламарчук (1994)) положення України. $С$ й ціла низка досліджень на дану тематику в близьких до політичної географії науках: С. Василенко (2002), Т. Возняк (2015), С. Плохій (2019b) тощо. А от спроб ранжування усіх держав світу відповідно до національних інтересів України на основі цілої низки важливих показників ми не зустріли як серед географічних, так і серед публікацій 3 інших сфер наукових досліджень.

Мета і завдання дослідження. Тож метою даного дослідження було формування рейтингу пріоритетності держав світу для розвитку такої усесторонньої співпраці, яка б найбільшою мірою відповідала національним інтересам нашої держави бути повноправним суб'єктом міжнародних відносин iз сучасним господарським комплексом і заможним населенням. Одночасно, на основі використання низки показників, ми прагнули:

- виявити реальну важливість усіх держав світу для України та їхню відповідність стратегічним національним інтересам нашої держави;

- виокремити групу держав, співробітництво 3 якими значно покращить безпекове, економічне та соціальне становище України і не нестиме загроз

(C) Валентин Стафійчук 
для ㄲï існування у якості суб’єкта міжнародних відносин;

- довести, що співпраця 3 агресором $\epsilon$ недоречною $з$ точки зору довгострокових національних інтересів України.

Методика дослідження. В основу формування рейтингу пріоритетності держав для України покладена бальна оцінка низки показників. Нами було відібрано 14 показників, як абсолютних, так і відносних, які характеризують різноманітні складові суспільно-географічної характеристики та потенціалу держав і визначають їхню вагу у сучасному світі та важливість для реалізації національних інтересів України й усестороннього розвитку нашої держави:

- чисельність населення (за даними Central Intelligence Agency, 2019a) - відображає демографічну вагу держави у сучасному світі, опосередковано об’єм внутрішнього ринку; найвищий бал отримали держави 3 населенням понад 100 млн осіб;

- чисельність української діаспори (за даними Faichak, 2018; Zubyk, 2016) - можливість впливу на двосторонні стосунки, політичне та економічне життя певної держави, використання діаспори для формування позитивного іміджу України, опосередковано - підвищення добробуту українських родин за рахунок надходження переказів від родичів; найвищий бал отримали держави, в яких чисельність діаспори перевищує 100 тис осіб;

- ВВП на душу населення (за даними International Monetary Fund, 2019) - показує рівень добробуту населення та можливу купівельну спроможність суспільства, опосередковано - інтеграція 3 такими державами є стимулом для суспільно-економічного розвитку; найвищий бал отримали держави, де дохід на душу населення перевищує 35 тис дол США за паритетом купівельної спроможності (ПКС);

- індекс економічної свободи (за даними The Heritage Foundation, 2020) - ілюструє низку фундаментальних прав i свобод (свободу від корупції, захист прав власності, свободу бізнесу, торгівлі та інвестицій, податкову свободу тощо) кожної людини та іноземних інвесторів, рівень втручання держави в економічні процеси, опосередковано - легкість розвитку двосторонніх стосунків. Варто зазначити, що розвиток співпраці з економічно вільними суспільствами стимулює до створення відповідних умов в Україні, що повністю корелюється із заявленими нашою державою цілями формування вільного ринку. Найвищий бал отримали економічно вільні суспільства 3 показником індексу понад 80;

- обсяг імпорту товарів з України з урахуванням балансу торгівлі (за даними International Trade Centre, 2020) - показує сучасних партнерів у торгівлі товарами та рівень залежності від їхніх ринків, прибутковість відповідної торгівлі, опосередковано важливість для розвитку господарського комплексу держави, його осучаснення та ситуацію на ринку зайнятості; найвищий бал отримали держави, об'єм експорту до яких перевищує понад 500 млн дол. США, а торгівля має позитивне сальдо;
- обсяг імпорту послуг з України (за даними Verner (Ed.), 2019) - аналогічно до попереднього, але стосовно ринку послуг; найвищий бал отримали держави, об'єм експорту українських послуг до яких перевищив 500 млрд дол США;

- глобальний інноваційний індекс (за даними Cornell SC Jonson College Business et al., 2020) - визначає інноваційний клімат країни, ступінь запровадження інновацій в економіці, освіті, державному управлінні, опосередковано - можливість доступу до них; найвищий бал отримали держави 3 глобальним інноваційним індексом понад 60;

- золотовалютні резерви (за даними Central Intelligence Agency, 2018) - свідчать про фінансову вагу держави, опосередковано - про можливість запозичень чи отримання фінансової допомоги у разі необхідності; найвищий бал отримали держави, золотовалютні резерви яких перевищують 100 млрд дол США;

- накопичені за кордоном прямі іноземні інвестиції (ПІІ) (за даними Central Intelligence Agency, 2019b) - відображають наявний інвестиційний потенціал певної держави, опосередковано - можливість залучення інвестицій Україною; найвищий бал отримали держави, чиї сумарні ПІІ за кордоном перевищують 1 трлн дол США;

- індекс демократії (за даними The Economist Intelligence Unit, 2020) - показує рівень розвитку та стійкості демократичних інститутів, свободи виборів, громадянських свобод, політичної культури, опосередковано - інтеграція і взаємодія 3 демократичними державами відповідає стратегічній меті побудувати вільне й демократичне суспільство в Україні; найвищий бал отримали держави 3 повноцінною демократією (індекс перевищує 8.0);

- індекс крихкості (за даними The Fund for Peace, 2019) - визначає рівень стійкості державних органів перед внутрішніми та зовнішніми загрозами, спроможність виконання ними своїх функцій i контролю ситуації, збереження стабільності і цілісності держави, опосередковано - надійність та відповідальність партнера; найвищий бал отримали держави, крихкість яких не перевищує 30 очок;

- підтримка цілісності та позицій України на міжнародному рівні (за даними United Nations 2014, 2019; MTsPD, 2019) - показує послідовність та надійність зовнішньополітичних партнерів у підтримці України; найвищий бал отримали держави, які підтримали усі резолюції Генеральної Асамблеї ООН стосовно України (A/RES/68/262, A/RES/71/205, A/RES/72/439, A/RES/73/263, A/RES/74/168) та запровадили і дотримуються санкцій щодо Росії у відповідь на її агресію в Україні;

- індекс військової сили (за даними Global Firepower, 2019) - відображає військовий потенціал держав, опосередковано - військово-технологічну потужність можливого партнера; найвищий бал отримали держави 3 індексом військової сили понад 2,250;

- участь у військово-політичних організаціях 
(за даними NATO, 2019; Collective Security Treaty Organization, 2019) - показує відповідність стратегічній меті України на членство в НАТО та можливість розвитку усестороннього співробітництва 3 членами i партнерами цієї організації, сучасне військово-стратегічне положення; опосередковано або у разі задекларованого вступу - підвищує рівень безпеки держави; найвищий бал отримали держави-члени НАTO.

Кожен 3 показників оцінювався за 5-бальною шкалою. Сума балів і визначила місце країни у рейтингу пріоритетності. У підсумку всі країни були об’єднані в 6 груп: понад 60, 50-59, 40-49, 30-39, 20-29 та до 20 балів, відповідно.

Виклад основного матеріалу. За даними проведеного дослідження, першу групу пріоритетності для України сформували 9 держав:

- Німеччина - 67 балів;

- США - 66 балів;

- Велика Британія - 65 балів;

- Італія, Канада, Нідерланди, Франція - по 61 балу;

- Іспанія, Швейцарія - по 60 балів.

Усі вищеперераховані держави є світовими або регіональними лідерами за багатьма показниками. Перш за все, вони мають високі стандарти рівня i якості життя населення та розвинуті демократичні інститути, які є орієнтиром для нашої держави. Усі активно підтримують територіальну цілісність України (навіть Італія 3 іiі традиційно сильним проросійським лобі дотримується санкцій стосовно Росіі), мають значний глобальний індекс сили та входять до НАТО (крім Швейцарії, яка є партнером НАТО), перспектива членства в якому прописана в Конституції України. Вагомими чинниками взаємодії 3 ними $\epsilon$ також значні золотовалютні резерви (крім Нідерландів), високий інвестиційний та інноваційний (крім Італії та Іспанії) потенціал.

Навіть посередні та низькі бали, які окремі держави отримали за ті чи інші показники (найчастіше - це обсяг імпорту товарів і послуг, чисельність української діаспори, глобальний інноваційний індекс та індекс економічної свободи), у підсумку не завадили їм увійти у першу групу пріоритетності. Цим ще раз підкреслюється важливість співробітництва 3 ними. Крім того, у цьому криється й потенціал підвищення місця окремих країн у рейтингу пріоритетності. Зокрема, розширення взаємної торгівлі товарами з Канадою і Швейцарією та послугами з Іспанією і Канадою, може не лише покращити їхнє місце у рейтингу, а й, що більш важливо, стимулювати якісні структурні зміни в господарському комплексі України. Звісно, що для цього, у першу чергу потрібна державна воля і зменшення впливу олігархів, які консервують аграрну й сировинну спеціалізацію та продовжують експлуатувати технологічно відсталі промислові підприємства. Розвиток взаємодії 3 більш інноваційними господарськими комплексами першої групи країн, на відміну від продовження співпраці з Росією, дає Україні додатковий шанс розвинути галузі 3 більшою доданою вартістю i відновити (ще раз зазначимо - при наявності сильної державної волі) чи створити заново імідж держави $з$ потужними і сучасними машинобудівним, нафтохімічним, металургійним, агропереробним комплексами; транзитним, науковим та інформаційно-технологічним потенціалом. А це, в свою чергу, підвищить рівень зайнятості та добробут українців у себе вдома.

Так само, покращення глобального інноваційного індексу або ситуації з економічною свободою можуть підвищити пріоритетність окремих країн для України. Україні варто також усіляко використовувати можливості діаспори, хай і не дуже чисельної, у Великій Британії, Нідерландах, Франції, Швейцарії для відстоювання i популяризації українських ідей і поглядів. Варто також активніше наголошувати на внеску українців - представників діаспори, яких часто у цих країнах вважають росіянами, у світову науку, освіту і мистецтво.

Отже, усебічна орієнтація України на співробітництво саме 3 цією групою держав $\epsilon$ неабиякою запорукою подальшого суспільного та економічного розвитку, посилення безпеки нашої держави, відновлення історичної справедливості й успіхів у боротьбі з російською брехнею.

До другої групи пріоритетності увійшли 19 держав:

- Японія - 59 балів;

- Ізраїль, Польща, Чехія - по 58 балів;

- Австрія - 57 балів;

- Бельгія, Данія, Швеція - по 56 балів;

- Австралія - 55 балів;

- Південна Корея, Португалія- по 54 бали;

- Норвегія, Румунія, Угорщина - по 53 бали;

- Сінгапур, Туреччина - по 52 бали;

- Ірландія, Фінляндія - по 51 балу;

- Словаччина - 50 балів.

Усі держави цієї групи, крім Сінгапуру, є членами Організації економічного співробітництва i розвитку (ОЕСР), а 12 з них - членами ЄС. Це група достатньо успішних в економічному (високі показники ВВП на душу населення, значні золотовалютні запаси (крім Ірландії та Словаччини), економічна свобода, високий і середній інвестиційний (крім Румуніiі) та інноваційний (крім Румунії й Туреччини) потенціали) i політичному (усталені демократичні інститути (крім Туреччини), високий рівень життєздатності держав (крім Ізраїлю й Туреччини)) відношеннях держав.

Надзвичайно важливим у цій групі $є$ те, що усі держави послідовно підтримують цілісність України, запровадили санкції проти Росії (крім Ізраїлю i Туреччини) та $є$ повноправними учасниками або партнерами НАТО.

Стосовно взаємної торгівлі товарами i послугами, то зміна їх обсягів може покращити позиції в рейтингу практично усіх держав 3 даної групи, оскільки лише Австрія, Ізраїль, Румунія й Туреччина, і то лише стосовно торгівлі товарами, отримали 5 балів. Низьким, особливо, зважаючи на 
існуючу взаємодоповнюваність господарств, є обсяг українського експорту товарів не лише до географічно віддаленої Австралії, а й до європейських Данії, Ірландії, Норвегіï, Фінляндії та Швеції (усі отримали лише по 1 балу). Те саме можна сказати і про обсяг торгівлі послугами 3 Австралією, Португалією, Сінгапуром, Словаччиною, Норвегією, Фінляндією (1-2 бали). Посилення взаємозалежності з успішними державами, окрім якісних змін в господарському комплексі, може бути стимулом для формування проукраїнського лобі в політичному та економічному істеблішменті відповідних держав і підтримці ним наших євроінтеграційних прагнень. Порівняно незначна чисельність населення у більшості з них, крім Японії та Туреччини, компенсується його високою купівельною спроможністю.

Дещо покращити місце окремих держав у рейтингу пріоритетності та позиції України у відповідних державах може й структуризація української діаспори, яка, як і українське суспільство в цілому, часто залишається фрагментованою й інколи навіть не ідентифікує себе з Україною, що й робить їі маловпливовою. Це стосується не лише Австралії, Австрії, Словаччини, Туреччини (особливо кримські татари), Угорщини, Фінляндії, Швеції, а й посилення ролі нашої діаспори в Ізраїлі, Польщі, Португалії, Румунії, Чехії.

Загалом, попри значну розбіжність в окремих показниках, це група дружніх до України та успішних на міжнародній арені держав, подальший розвиток співробітництва 3 якими, цілком відповідає стратегічним цілям i національним інтересам України.

Третю групу пріоритетності для України сформували 26 держав, а саме:

- Болгарія, Малайзія - по 48 балів;

- Китай, Нова Зеландія, Росія - по 47 балів;

- Бразилія, Греція, Естонія, Латвія, Таїланд - по 46 балів;

- Аргентина, Індія, Литва, Мексика, ОАЕ - по 45 балів;

- Ісландія, Люксембург - по 44 бали;

- Саудівська Аравія, Словенія, Чілі - по 43 бали;

- Кіпр, Хорватія - по 42 бали;

- Азербайджан, Індонезія, Молдова, Філіппіни по 40 балів.

У порівнянні з двома попередніми, це більш різноманітна за набором держав група. Наприклад, поряд 3 такими демографічними гігантами як Китай та Індія тут перебувають Люксембург та Ісландія; поряд з членами НАТО і країнами, які підтримують територіальну цілісність України, - Росія і Китай; поряд із демократичними Новою Зеландією, Ісландією, Люксембургом і Чілі - авторитарні Китай, Саудівська Аравія, ОАЕ, Азербайджан і Росія; поряд з Китаєм, який нині є потужним інвестором, - малопомітна у цьому відношенні Молдова; поряд 3 важливими імпортерами українських товарів i послуг - відверті аутсайдери тощо. Проте сукупність усіх показників урівнює в пріоритетності для України Китай, Росію та Індію з Естонією, Чилі чи OAE. 3 позицій національних інтересів, подальше розширення співробітництва 3 Хорватією або Молдовою $є$ набагато важливішим для України, ніж відновлення довоєнних стосунків з Росією. Ці держави, на відміну від останньої, не становлять загрози існуванню України, не створюють викликів для внутрішньої стабільності і не дискредитують нашу державу на міжнародній арені. Крім того, вони мають спільні з Україною інтереси: розвиток демократичних стандартів, запровадження повноцінних ринкових механізмів, курс на зміцнення членства або подальшу інтеграцію в євро-атлантичні структури і світове співтовариство.

Беручи до уваги ті критерії, які найбільшою мірою відповідають національним інтересам України, варто виокремити підгрупу найбільш успішних в економічному плані, демократичних i дружніх нам держав: Естонія, Литва, Латвія, Хорватія, Словенія, Нова Зеландія, Люксембург, Ісландія, Болгарія, Греція, Кіпр. Саме на розвитку усебічної дво- та багатосторонньої співпраці з ними і сусідньою Молдовою Україні й варто робити акцент. За багатьма складовими рейтингу ці країни подібні до другої групи пріоритетності.

Також варто намагатися покращити рівень взаємодії 3 окремими регіональними лідерами, державами-членами ОЕСР та важливих регіональних інтеграційних об'єднань (наприклад, АСЕАН). Саме такими є Індія, Бразилія, Мексика, Аргентина, Чилі, Індонезія, Таїланд, Малайзія, Філіппіни. Передумовами для цього $€$ взаємодоповнюваність господарських комплексів, ємність ринків, відносні економічні та демократичні свободи, наявність в окремих із них значної української діаспори.

Важливою, особливо з точки зору диверсифікації постачання енергоресурсів або галузевої структури господарства, але не за рахунок нехтування національними інтересами i демократичними цінностями, має бути і співпраця 3 Саудівською Аравією, Азербайджаном та ОАЕ.

Нині ведуться запеклі дискусії, у тому числі і в Україні, стосовно місця й ролі Китаю у сучасному світі та необхідності розвивати 3 ним усебічну співпрацю. У 2019 р. Китай став головним торговельним партером для нашої держави: на нього припадало 14,4\% українського імпорту товарів (1-е місце) та 9,0\% - експорту (2-е місце) (International Trade Centre, 2020). Він здійснює важливі для України інвестиційні та інфраструктурні проєкти, у тому числі в рамках ініціативи «Один пояс і один шлях» (часто всупереч діям Росії); розвиває освітньо-культурне співробітництво (обмін студентами і науковцями, діяльність відділень Інституту Конфуція, спільні культурні проєкти тощо). Водночас слід зазначити, що за рахунок торгівлі товарами з Китаєм формується найбільший дефіцит торгівлі: -2,9 млрд дол США у 2019 р (у 2018 р він становив взагалі рекордні 5,4 млрд дол США).

Китай хоч і не визнає анексії Росією українського Криму, проте не голосував за жодну із резолюції $\mathrm{OOH}$, які підтримують територіальну цілісність України та засуджують порушення Росією прав людини в Криму та не підтримує санкцій проти РФ. 
Більше того, окремі китайські компанії продовжили співробітництво 3 кримськими підприємствами й після анексії півострова.

Варто завжди пам'ятати, що залишаючись високоцентралізованою експансивною комуністичною диктатурою, Китай має додаткові, далекі від ринкових, важелі для посилення конкурентоспроможності власної продукції та ii просування на світовому ринку. Своїми закордонними інвестиціями і фінансовими преференціями він уже забезпечив собі вплив навіть у високорозвинених державах. Разом 3 тим, Китай всіляко намагається обійти або проігнорувати існуючі правила світоустрою. У стосунках 3 ним також криється небезпека національним інтересам України: деіндустріалізація, сировинна спеціалізація, технологічне та кібернетичне шпигунство, корупційні схеми тощо. Жодною мірою, розвиток взаємовідносин 3 Китаєм не має зашкодити стосункам 3 країнами $\mathrm{CC}$, а тим паче хоч якось зіштовхнути Україну з ними: вже $є$ сумний досвід Греції та Угорщини, де китайські інвестиції зумовили протистояння цих країн з СС, у тому числі через нехтування ними демократичними цінностями на догоду КНР. Не можуть бути орієнтирами для України і стандарти, на основі яких Китай вибудовує внутрішнє політичне та економічне середовище.

Зважаючи на одне із завдань, яке ми ставили перед собою у даній статті, детальніше зупинимося на місці Росії у рейтингу пріоритетності для України. Разом 3 Китаєм та Новою Зеландією вона поділяє лише 31 сходинку рейтингу. Показовим $є$ i те, що пріоритетність Росії для України є приблизно такою ж як Естонії, Ісландії чи Молдови. Це цілком логічно i закономірно як для колишнього колонізатора i нинішнього ворога. На нашу думку, це ще й занадто високий рівень пріоритетності.

Найвищі бали Росія отримала за такі показники як чисельність населення, золотовалютні резерви, глобальний індекс сили (значною мірою успадкований від СРСР), чисельність української діаспори (сформувалася як природним, так і насильницькими методами) і обсяг торгівлі послугами. Водночас, ті показники, які найбільшою мірою формують привабливість будь-якої країни та відповідають українським національним інтересам - індекс демократії, економічна свобода, інноваційність господарства, дієздатність держави, участь у відповідних військово-політичних організаціях, підтримка цілісності - є критично низькими.

Росія досі залишається важливим імпортером українських товарів і послуг. Проте, як нами вже зазначалося у попередній статті (Stafiichuk, 2017), торгівля з Росією в умовах загарбання нею частини території і вже на 7-му році відкритої російської агресії - це взагалі нонсенс. Структура торгівлі як товарами, так і послугами не витримує жодної критики і є прямою загрозою національній безпеці України. За рахунок торгівлі товарами 3 Росією формується значне від'ємне сальдо: лише 32014 р воно коливалося у межах від 1,6 (2016 р) до 4,4 млрд дол США (2018 p) (International Trade Centre, 2020), що консервує колоніальну і формує фінансову залежність від агресора. Надзвичайно незбалансованою залишається і товарна структура україно-російської торгівлі. Посилення ж залежності від Росії на ринках стратегічної або критично важливої продукції, особливо енергоносіїв, взагалі створює загрози для існування не лише господарського комплексу, а й незалежності загалом. «Вигідність та необхідність» торгівлі з Росією - це такий же міф, як і багато інших в системі «русского мира».

Проте ii продовжують лобіювати проросійські політики і олігархи, які зацікавленні у збереженні колоніальної залежності України, працюють за усталеними корупційними схемами, доводять до банкрутства цілі галузі української промисловості (яскравий приклад - нафтопереробка), щоб ще більше прив'язати Україну до російського ринку та не дати розвинути власний сучасний господарський комплекс.

У таблиці 1 наведене порівняння окремих цілей, які випливають із концепцій стратегічного розвитку та відповідних законодавчих актів, що відображають національні інтереси України і Росії. Як бачимо, якщо не брати до уваги загальні фрази, вони суттєво відрізняються за усіма конкретними цілями.

Проросійські сили в Україні в унісон 3 російською пропагандою агресивно просувають тези «русского мира», намагаються довести недієздатність української держави без «дружби» (по суті - повної капітуляції) 3 Росією та їі повну залежність від США. Саме місце Росії в третій групі пріоритетності вже $є$ вагомим контраргументом для тих в Україні, хто досі ратує за «першочерговість» «братніх» стосунків з Росією. Цілі цих держав завжди були, а нині тим більше $\epsilon$, дуже різними, тому Росія жодним чином не може бути ні стратегічним, ні важливим партнером для України.

Як додатковий аргумент проти взаємодії 3 потужними недемократичними суспільствами,як от Росія чи Китай, слід згадати слова С. Плохія (2019b, С. 391) про так і незасвоєний урок XX століття: «Як показує Ялта, незалежно від того, наскільки сильно стараються демократичні лідери, творення альянсів із диктатурами та тоталітарними режимами завжди має свою ціну». І стосується це не лише політичної сфери: у таких суспільствах як російське або китайське, політикою просякнуте усе - господарство, зовнішня торгівля, ЗМI, культура, спорт тощо.

Отже, три перші групи пріоритетності охоплюють 54 держави або понад чверть усіх незалежних держав світу. Приналежність держав до інших груп жодною мірою не означає, що вони не мають знаходитися в полі зору України. Наприклад, особливу увагу слід приділяти дипломатичним, економічним i культурним зв'язкам 3 незгаданими раніше європейськими державами, демократичними державами Латинської Америки, Азії, Африки та успішними країнами Близького Сходу. На нашу думку, такими є:

- 3 четвертої групи пріоритетності - Грузія, Мальта, Казахстан (по 39 балів), Уругвай, Перу 
Порівняння окремих цілей розвитку України та Росії (оновлено Stafiichuk, 2012)

\begin{tabular}{|c|c|}
\hline \multicolumn{2}{|c|}{ Стратегічна ціль } \\
\hline Україна & Росія \\
\hline Збереження державного суверенітету & $\begin{array}{l}\text { Збереження та посилення російського впливу на } \\
\text { пострадянському просторі, аж до відновлення єдиної } \\
\text { держави; концепція «зони виключних російських } \\
\text { інтересів» }\end{array}$ \\
\hline Вступ до ЄС & $\begin{array}{l}\text { Втягнення України у Митний союз, САЕС та інші } \\
\text { інтеграційні утворення на пострадянському просторі }\end{array}$ \\
\hline Цілісність державної території & $\begin{array}{l}\text { Подальша окупація Криму, частини Донбасу; } \\
\text { заохочення сепаратистських рухів та дестабілізації у } \\
\text { різних частинах України }\end{array}$ \\
\hline Чітке визначення і контроль державних кордонів & $\begin{array}{l}\text { Відмова передати Україні контроль над ділянками } \\
\text { окупованих сухопутних та морських кордонів; } \\
\text { існування «вільних» кордонів; всіляке відтермінування } \\
\text { делімітації та демаркації україно-російського кордону }\end{array}$ \\
\hline Європейська ідентичність & Євразійство \\
\hline Українська політична та етнічна ідентичність & $\begin{array}{l}\text { Ідеологія «русского мира», українці (малороси) - } \\
\text { складова російського етносу }\end{array}$ \\
\hline $\begin{array}{l}\text { Розвиток і розширення сфери вжитку української } \\
\text { мови як єдиної державної }\end{array}$ & $\begin{array}{l}\text { «Захист» російськомовного населення та продовження } \\
\text { росієфікації; надання російській мові статусу } \\
\text { державної в Україні }\end{array}$ \\
\hline $\begin{array}{l}\text { Формування позитивного іміджу держави на } \\
\text { міжнародній арені }\end{array}$ & Дискредитація України на міжнародній арені \\
\hline Вступ до НАТО & Запобігання розширенню НАТО \\
\hline $\begin{array}{l}\text { Відсутність іноземних військових баз в межах } \\
\text { держави }\end{array}$ & Збереження військової присутності в Криму \\
\hline $\begin{array}{l}\text { Зміцнення помісної Православної Церкви України; } \\
\text { відновлення історичної правди про українське } \\
\text { православ’я і греко-католицизм; поліконфесійність }\end{array}$ & $\begin{array}{l}\text { Збереження підпорядкування Української Право- } \\
\text { славної Церкви єдиній Російській православній } \\
\text { Церкві } 3 \text { центром у Москві; збереження міфу про } \\
\text { «тисячоліття православ’я в Росії» }\end{array}$ \\
\hline $\begin{array}{l}\text { Розбудова сучасного високотехнологічного, } \\
\text { наукоємного, енергозберігаючого та експортно- } \\
\text { орієнтованого господарства }\end{array}$ & $\begin{array}{l}\text { Збереження енергетичної та колоніальної залежності } \\
\text { української промисловості і сільського господарства; } \\
\text { подальша деіндустріалізація та маргіналізація } \\
\text { українських земель }\end{array}$ \\
\hline $\begin{array}{l}\text { Відновлення історичної пам’яті про Русь-Україну, } \\
\text { Запорізьку Січ, національно-визвольні рухи XVII- } \\
\text { XX ст., Голодомор, Другу світову війну тощо }\end{array}$ & $\begin{array}{l}\text { Збереження існуючих історичних міфів про } \\
\text { «спільну колиску», «тисячолітню спільну історію», } \\
\text { «цивілізаційну місію росіян», Велику Вітчизняну } \\
\text { війну тощо }\end{array}$ \\
\hline $\begin{array}{l}\text { Розвиток україномовних книгодрукування, кіно, } \\
\text { 3МІ }\end{array}$ & $\begin{array}{l}\text { Збереження і розширення російського інформаційного } \\
\text { простору }\end{array}$ \\
\hline $\begin{array}{l}\text { Вшанування національних героїв, борців за свободу } \\
\text { України, героїв Небесної сотні та визначних діячів }\end{array}$ & $\begin{array}{l}\text { Таврування всіх, хто говорив про окремішність та } \\
\text { прагнув незалежності України у державній, церковній, } \\
\text { науково-освітній, мовно-культурній сферах; підтримка } \\
\text { ідеї меншовартості українців }\end{array}$ \\
\hline
\end{tabular}

(38 балів), Єгипет (37 балів), Північна Македонія, Південна Африка, Панама, Нігерія, Алжир (по 36 балів), Албанія, Туніс, Коста-Ріка (по 35 балів), Йорданія, Бахрейн (по 34 бали), Чорногорія, Пакистан (по 33 бали), Шрі-Ланка, Ботсвана, Парагвай (по 32 бали), Вірменія (31 бал);

- 3 п’ятої групи пріоритетності - Танзанія, Кенія (по 29 балів), Киргизстан (26 балів), Косово (24 бали; вважаємо, що Україна має визнати незалежність цієї держави).
Співпраця 3 цими державами дасть змогу не лише диверсифікувати зовнішні зв'язки, а й стимулювати розвиток галузей господарювання 3 більшою доданою вартістю, а, відповідно, підвищити рівень життя в Україні. Подальше поглиблення співпраці та обопільне підвищення стандартів життя може суттєво вплинути на взаємну пріоритетність зазначених держав і України та сформувати коло дружніх держав. У будьякому разі, перевагу слід віддавати рівноправним 
відносинам, а не стосунками міфічного «старшого» брата 3 «меншим».

Висновки i перспективи подальших досліджень. Розробка конструктивної геостратегії України 3 урахуванням національних інтересів i реалій світового співтовариства вимагає більш чіткої ідентифікації друзів i ворогів. 3 метою покращення безпекової та економічної ситуації, Україні у першу чергу потрібно інтенсифікувати різнопланові зв'язки 3 державами першої та другої груп пріоритетності, особливо членами СС і НАТО, адже взаємодіяти із потужними, демократичними i доброзичливими державами 3 подібними стратегічними цілями набагато вигідніше, ніж тими, які усім своїм існуванням намагаються знищити або скомпрометувати все українське: історію, ідентичність, мову. Дотримуючись задекларованого вектору на вступ до вищеозначених організацій, Україна має дбати про взаємовигідне дво- та багатостороннє співробітництво 3 іншими державами світу відповідно до своїх національних інтересів. При цьому варто зважати на те, що розвивати всебічну співпрацю навіть 3 невеликими, проте демократичними і економічно успішними країнами - більш доцільно, ніж з потужними авторитарними суспільствами, підіграючи амбіціям диктаторів і потрапляючи у їхні пастки. У будь-якому разі Україна має докладати зусиль для розбудови рівноправних взаємовідносин.
На даному етапі співробітництво $з$ Росією, яка веде агресивну компанію на знищення України як самостійного гравця на міжнародній арені, не відповідає національним інтересам. Проблема Україниу тому, що за роки незалежності так і не було диверсифіковано зовнішньополітичний та зовнішньоекономічний комплекси і всі зусилля спрямовувалися на збереження колоніальної залежності. Лише після 2014 р відбулися певні позитивні зрушення, але досі існує реальна загроза реваншу проросійських сил $\mathrm{i}$ відкату назад. Головним критерієм у розвитку стосунків мають стати власні національні інтереси і стратегічні цілі. I саме відповідно до них, Росія не може бути ні стратегічним, ні важливим партнером для України.

Ми акцентували увагу лише на окремих моментах рейтингу, проте він дає набагато більше можливостей для подальших роздумів, аналітики i удосконалення, як і для критики.

Отже, складений рейтинг пріоритетності дає змогу виокремити ті держави, співробітництво 3 якими найбільшою мірою відповідає національним інтересам України і гарантує збереження незалежності. Його також можна удосконалювати або використовувати при розрахунках пріоритетності для інших держав. Головним же пріоритетом для України мають залишатися і1і національні інтереси та курс на повноправне членство в НАТО і СС.

\section{References:}

Central Intelligence Agency. (2018). Reserves of Foreign Exchange and Gold.Retrieved from: https://www.cia. gov/library/publications/resources/the-world-factbook/fields/245rank.html\#AG.

Central Intelligence Agency. (2019a). Population. Retrieved from: https://www.cia.gov/library/publications/ resources/the-world-factbook/fields/335rank.html\#AG.

Central Intelligence Agency. (2019b). Stock of Direct Foreign Investment - Abroad. Retrieved from: https://www. cia.gov/library/publications/the-world-factbook/fields/248rank.html \#KG

Collective Security Treaty Organization. (2019). From the Treaty to the Organization. [In Russian]. [От Договора к Организации. Retrieved from: https://odkb-csto.org/25years/].

Cornell SC Johnson College of Business, WIPO \& INSEAD. (2020). Global Innovation Index 2019. Retrieved from: http://www.euroosvita.net/prog/data/attach/6151/global-innovation-index-2019_full.pdf.

Dnistrianskyi, M. S. (2010). Political Geography and Geopolitics of Ukraine. Ternopil: Navchalnaknyha Bohdan. [In Ukrainian]. [Дністрянський М. С. Політична географія та геополітика України / Навч. посібник. Тернопіль, Навчальна книга - Богдан, 2010. 344 с.]

Faichak, I. (2018). Ukrainian Diaspora. [In Ukrainian]. [Файчак I. Українська діаспора. 2018. Retrieved from: https://ridna-ukraina.com.ua/contemporary-ukraine/ukrainska-diaspora.html.

Global Firepower. (2019). 2019 Military Strength Ranking. Retrieved from: https://www.globalfirepower.com/ countries-listing.asp.

International Monetary Fund. (2019). Report for Selected Countries and Subjects. 2018. Retrieved from: https:// www.imf.org/external/pubs/ft/weo/2019/01/weodata/weorept.aspx?sy=2018\&ey.

International Trade Center. (2020). List of Importing Markets for the Product Exported by Ukraine in 2019. Retrieved from: https:/www.trademap.org/Country_SelProductCountry.aspx?nvpm=1\%7c804\%7c\%7c\%7c\%7cTOTA $\mathrm{L} \% 7 \mathrm{c} \% 7 \mathrm{c} \% 7 \mathrm{c} 2 \% 7 \mathrm{c} 1 \% 7 \mathrm{c} 2 \% 7 \mathrm{c} 2 \% 7 \mathrm{c} 1 \% 7 \mathrm{c} \% 7 \mathrm{c} 2 \% 7 \mathrm{c} 1 \% \overline{\mathrm{c}} 1 \% 7 \mathrm{cl}$.

Khorosheniuk, S. I. (2017). Cooperation Between Ukraine and the Baltic Countries in the Context of European Integration Processes. (Thesis of PhD dissertation). Chernivtsi. [In Ukrainian]. [Хорошенюк С. І. Співробітництво України та країн Балтії в контексті євроінтеграційних процесів: дис. канд. політ. наук: 23. 00. 04. Чернівці, 2017. 211 c.]

Klochko, R. Yu. (2007). Socio-Geographical Analysis of the Geopolitical Position of Ukraine in Modern Europe. (Thesis of PhD dissertation). Kуiv. [In Ukrainian]. [Клочко Р. Ю. Суспільно-географічний аналіз геополітичного положення України у сучасній Свропі : дис. канд. геогр. наук: 11.00.02. К., 2007. 162 с.]

Koroma, N. (2007). The place of Ukraine in the formation of the Baltic-Black Sea region: from idea to real 
cooperation. Bulletin of Taras Shevchenko National University of Kyiv. Geography, 54, 55-57. [In Ukrainian]. [Корома Н. С. Місце України у формуванні Балто-Чорноморського регіону: від ідеї до реального співробітництва // Вісник Київського національного університету імені Тараса Шевченка. Географія. Т. 54. С. 55-57].

Kramar, O. (2020, June 19-25). Enable survival instinct. The Ukrainian Week, 25 (657), 19. [In Ukrainian]. [Крамар О. Увімкнути інстинкт виживання // Український тиждень. 2020. №25 (657). С. 19]

Lavrinenko, S. (2014). Current geopolitics location of Ukraine in the works of native scientists. Ekonomichna ta Sotsialna Geografiya, 69, 3-11. [In Ukrainian]. [Лавриненко С. Сучасне геополітичне положення України у працях вітчизняних учених // Економічна та соціальна географія. 2014. Вип. 69. С. 3-11]

Lototskyi, S. \& Trokhymchuk, S. (2002). Ukraine in the World Geopolitical Space. Lviv: Lviv National Univesity. [In Ukrainian]. [Лотоцький С., Трохимчук С. Україна в світовому геополітичному просторі. Львів: Вид-во ЛНУ, 2002. 192 c.]

Malskyi, M. \& Kuchyk, O. (2013). Organization for Democracy and Economic Development - GUAM as a project and regional leadership of Ukraine: problems and prospects. Bulletin of the Lviv University. (Series "International Relations»), 32, 47-54. [In Ukrainian]. [Мальський М., Кучик О. Організація за демократію і економічний розвиток - ГУАМ як проект регіонального лідерства України: проблеми та перспективи // Вісник Львівського університету. Серія: Міжнародні відносини. 2013. Вип. 32. С. 47-54]

Malynovska, O. \& Stafiichuk, V. (2017). Current regional political and geographical position of Ukraine. World Science, 12 (28), 1, 62-68.

Melnychuk, A. \& Stafiichuk V. (2011). Ukraine in a multipolar global political space. Scientific journal of M.P. Drahomanov NPU. (Series 4. "Geography and modernity»), 15 (27), 201-208. [In Ukrainian]. [Мельничук А. Л., Стафійчук В. І. Україна в багатополярному глобальному політичному просторі // Науковий часопис НПУ імені М. П. Драгоманова. Серія 4. Географія і сучасність. 2011. Вип. 15 (27). С. 201-208]

Morhatskyi, V. (2019). Structural geostrategy of Ukraine concerning post-Soviet countries in new geopolitical realities. Ekonomichna ta Sotsialna Geografiya, 82, 34-49. [In Ukrainian]. [Моргацький В. Конструктивна геостратегія України щодо держав пострадянського простору // Економічна та соціальна географія. 2019. Вип. 82. C. 34-49.]

MTsPD. (2019). Sanctions Against Russia. Current State, Prospects, Successes and Gaps of the Multilateral International Sanctions Regime Against the Russian Federation. [In Ukrainian]. [Санкції проти Росії. Нинішній стан, перспективи, успіхи та прогалини багатостороннього міжнародного санкційного режиму проти Російської Федерації. Київ: МЦПД, 2019. 47 c. Retrieved from: http://icps.com.ua/assets/uploads/images/files/t sankcii rf a4 ukr.pdf.

NĀTO. (2019). North Atlantic Treaty Organization. [In Ukrainian]. [Організація Північноатлантичного договору. Retrieved from: https://www.nato.int/cps/uk/natohq/index.htm]

Palamarchuk, M. \& Palamarchuk, O. (1994). Geopolitical position of Ukraine (essence and main features). Ukrainian Geographical Journal, 1-2, 3-8. [In Ukrainian]. Паламарчук М. М., Паламарчук О. М. Геополітичне положення України (сутність і основні риси) // Український географічний журнал. 1994. № 1-2. С. 3-8]

Plokhy, S. (2019a). The Price of Freedom. In The Gates of Europe (pp. 433-444). Kharkiv: Knyzhkovyi Klub «Klub Simeinoho Dozvillia». [In Ukrainian]. [Плохій С. Ціна свободи // Брама Європи; пер. $з$ англ. Романа Клочка. Харків: Книжковий Клуб «Клуб Сімейного Дозвілля», 2019. С. 433-444]

Plokhy, S. (2019b). Yalta. The Price of Peace. Kharkiv: Knyzhkovyi Klub «Klub Simeinoho Dozvillia». [In Ukrainian]. [Плохій С. Ялта. Ціна миру; пер. з англ. Надії Коваль. Харків: Книжковий Клуб «Клуб Сімейного Дозвілля», 2019. С. 391]

Shablii, O. (2004). Ukraine. In H. de Blii \& P. H.Muller. Geography: Worlds, Regions, Concepts (pp. 152-155). Kyiv: Lybid. [In Ukrainian]. [Шаблій О. Україна // Блій Г. де, Муллер П. Г. Географія: світи, регіони, концепти. [Переклад з англ.]. К.: Либідь, 2004. С. 152-155.]

Slyvka, R. (2011). Ukraine's buffer position: commonality and conflict of interests of major world players in Central and Eastern Europe. Geography and Tourism, 15, 195-201. [In Ukrainian]. [Сливка Р. Буферне положення України: спільність та конфлікт інтересів великих світових гравців у Центрально-Східній Європі // Географія та туризм. 2011. Вип. 15. С. 195-201]

Stafiichuk, V. (2012). Political and geographical analysis of development strategies of Ukraine and Russia. Geography and Tourism, 22, 211-218. [In Ukrainian]. [Стафійчук В. I. Політико-географічний аналіз стратегій розвитку України та Росії // Географія та туризм. 2012. Вип. 22. С. 211-218]

Stafiichuk, V. (2017). Ukrainian-Russian trade: political and economic-geographical aspects of interaction with the occupier. In Current State and Prospects of Economic Development, Accounting, Finance and Management in Ukraine and the World (pp. 27-29). Poltava: TsFEND. [In Ukrainian]. [Стафійчук В. Україно-російський товарообіг: політико- та економіко-географічні аспекти взаємодії з окупантом // Збірник тез доповідей Міжнародної науково-практичної конференції «Сучасний стан та перспективи розвитку економіки, обліку, фінансів та управління в Україні та світі» (м. Полтава, 14 листопада 2017 р.). Полтава: ЦФЕНД, 2017. С. 27-29]

The Economist Intelligence Unit. (2020). Democracy Index 2019. Retrieved from: https://www.eiu.com/topic/ democracy-index.

The Fund for Peace. (2019). Fragile States Index. Retrieved from: https://fragilestatesindex.org/data/

The Heritage Foundation. (2020). Highlights of The 2019 Index of Economic Freedom. Retrieved from: https:// 
www.heritage.org/index/pdf/2019/book/highlights.pdf.

United Nations. (2014). Voting Record on Draft Resolution A/68/L.39 Territorial Integrity of Ukraine. Retrieved from: https://papersmart.unmeetings.org/en/ga/68th-session/plenary-meetings/documents/voting-record/resolution$68262 /$.

United Nations. (2019). General Assembly Resolutions. Retrieved from: https://www.un.org/en/sections/ documents/general-assembly-resolutions/index.html.

Vasylenko, S. (2002). Geopolitical Dimensions of Ukraine in the Pan-European Political Process. (Thesis of Doctoral dissertation). National Academy of Sciences of Ukraine. Kuras Institute of Political and Ethnic Studies, Kyiv. [In Ukrainian]. [Василенко С. Д. Геополітичні виміри України в загальноєвропейському політичному процесі: автореф. дис. на здобуття наук. ступеня д-ра політ. наук: 23.00.02. Ін-т політ. і етнонац. дослідж. НАН України. К., 2002. 35 с.]

Verner, I. (Ed.). (2019). Statistical Yearbook of Ukraine for 2018. Zhytomyr: TOV «BUK-DRUK» [In Ukrainian]. [Статистичний щорічник України за 2018 рік. / За ред. Вернера I. Є. Житомир: ТОВ «БУК-ДРУК», 2019. C. 382-383]

Vozniak, T. (2015). Geopolitical Contexts of the War in Ukraine. Lviv: Yi. [In Ukrainian]. [Возняк Т. Геополітичні контексти війни в Україні. Львів, «ї», 2015. 95 с.]

Zubyk, A. (2016). Modern Ukrainian Diaspora: Resettlement, Socio- and Demogeographical Processes. (PhD dissertation). Lviv. [In Ukrainian]. [Зубик А. І. Сучасна українська діаспора: розселення, соціо- і демогеографічні процеси: дис. канд. геогр. наук: 11.00.02. Львів, 2017. 340 с.] 